\title{
Konstruksi Identitas Guru Bimbingan Konseling sebagai Komunikator Pendidikan
}

\author{
Putri Astiti ${ }^{1}$, Jenny Ratna Suminar ${ }^{2}$, dan Agus Rahmat ${ }^{3}$ \\ ${ }^{1}$ Universitas Bandung Raya \\ ${ }^{2,3}$ Universitas Padjadjaran
}

\begin{abstract}
ABSTRAK
Penelitian ini bermula dari dihilangkannya jam kelas bagi guru bimbingan dan konseling (BK) serta masih kurangnya jumlah guru BK di SMA Negeri di Kota Bandung. Peneliti ingin mengkaji lebih jauh mengenai motivasi, makna profesi, dan pengalaman komunikasi yang dialami oleh guru BK. Penelitian ini menggunakan metode kualitatif dengan pendekatan fenomenologi. Pendekatan ini mencoba untuk mencari pemaknaan mengenai bagaimana manusia mengkonstruksi makna dan konsep-konsep penting dalam kerangka intersubjektivitas. Pada penelitian ini data diperoleh dari tujuh guru BK sebagai key informant. Hasil penelitian ini menunjukkan tiga kategori yang melatarbelakangi alasan untuk menjadi guru, yaitu keinginan pribadi, arahan orang tua dan lingkungan pergaulan atau pertemanan. Hasil penelitian ini juga memunculkan dua kategori makna identitas guru BK, yaitu makna positif dan makna negatif. Makna positif dinyatakan pada guru sebagai orang tua, dicintai anak-anak, membantu siswa mengenali dirinya, harus tahu segala hal, dan guru yang sempurna. Makna negatif dinyatakan pada guru sebagai ganjal pintu dan guru yang masih dianggap sebagai polisi sekolah. Pengalaman komunikasi guru BK berlangsung pada konteks komunikasi antarpribadi, kelompok dan organisasional. Guru BK sebagai komunikator pendidikan harus memiliki kompetensi pedagogik, kepribadian, sosial dan profesional. Gambaran kondisi guru BK dalam memaknai profesi diharapkan dapat dijadikan rujukan pengambil kebijakan agar lebih memahami secara mendalam mengenai pentingnya keberadaan guru BK di sekolah.
\end{abstract}

Kata-kata Kunci: Guru bk; identitas diri; komunikator pendidikan; konstruksi identitas; makna diri

\section{Identity Construction of School Counselor as Education Communicator}

\begin{abstract}
This research initiated due to the shortage of high school counselor in Bandung and the removal of their teaching class in school. Researcher want to dig deeper in terms of motivation, meaning, and the communication experience of the school counselor. This research uses qualitative method with phenomenology approach. The goal is to find an understanding of how human construct important means and concept in terms of intersubjectivity. Data obtained from seven school counselor as key informant. This research shows that there are three categories of why someone becomes a school counselor, which is personal interest, parental guidance, and social circle. The research also shows that there is two category of means, positive and negative means. The positive means are being a parent to the student, loved, helping student to know themselves, knows various things, and being the perfect teacher. The negative means are being a spare teacher and considered as 'school police'. Communication experience of school counselor occurred in interpersonal, group, and organizational context. The school counselor as education communicator must have a range of competencies such as pedagogic, personality, social, and professional. The image of how school counselor give means to their profession is expected to give a references to the decision maker so that they can understand more of the importance of the school counselor.
\end{abstract}

Keywords: Education communicator; identity construction; school counselor; self identity; self means

Korespondensi: Putri Astiti, S.I.Kom., M.I.Kom. Fakultas Keguruan dan Ilmu Pendidikan Universitas Bandung Raya. Jl. Banten No. 11, Kebonwaru, Batununggal, Kota Bandung, Jawa Barat 40272. Email: putri_ astiti@rocketmail.com

Submitted: January 2016, Accepted: December 2017, Published: June 2018

ISSN: 2303-2006 (print), ISSN: 2477-5606 (online). Website: http://jurnal.unpad.ac.id/jkk

Terakreditasi Kemenristekdikti RI SK No. 48a/E/KPT/2017 


\section{PENDAHULUAN}

Bimbingan dan konseling adalah upaya pemberian bantuan kepada peserta didik dengan menciptakan lingkungan perkembangan yang kondusif, dilakukan secara sistematis dan berkesinambungan, supaya peserta didik dapat memahami dirinya agar sanggup mengarahkan diri dan dapat bertindak secara wajar sesuai dengan tuntutan tugas-tugas perkembangan. Kartadinata menyebutkan bahwa guru BK (konselor) adalah pendidik yang memfasilitasi perkembangan seluruh potensi siswa dari berbagai aspek, mulai dari pribadi, psikologi, maupun sosial. Guru BK memberikan bimbingan dalam menyiapkan siswa menentukan pilihannya secara mandiri (Sukmadinata, 2007: 1).

Peran penting sekolah adalah dalam pendidikan generasi muda. Sementara itu, ujung tombaknya adalah para guru sebagai pengajar yang memberi teladan dan ilmu yang diperlukan untuk mengarahkan dan membimbing generasi muda. Namun, ada guru yang lebih berperan aktif terhadap psikologi siswa. Ia adalah guru BK yang berperan untuk memfasilitasi perkembangan potensi siswa dalam aspek pribadi, sosial, belajar, karier dan perkembangan pribadi siswa. Berbeda dengan guru mata pelajaran yang konteks tugas pembelajarannya hanya berfokus pada mata pelajaran bidang studi, konteks tugas guru BK adalah kondisi pribadi siswa.

Dalam prakteknya sekarang ini, kontras dengan peran luhur guru BK dalam pendidikan, mereka seringkali termarjinalkan. Mulai dari tidak diberinya jam kelas, dianggap sebagai sekedar pengisi jam pelajaran kosong, sampai sering dianggap sebagai 'polisi sekolah'. Padahal peran mereka jauh dari itu, bahkan bertolak belakang. Mereka haruslah dekat dengan siswa. Menjadi tempat yang nyaman para siswa untuk berkonsultasi, bertanya halhal personal terkait perkembangan diri siswa, bahkan sekedar mengobrol santai.

Oleh karena itu, seorang guru BK harus memiliki kepribadian yang baik. Kepribadian seorang konselor merupakan faktor yang paling penting dalam konseling. Surya (2009: 57) mengungkapkan bahwa:

Kepribadian konselor merupakan titik tumpu yang berfungsi sebagai penyeimbang antara pengetahuan mengenai dinamika perilaku dan keterampilan terapeutik. Ketika titik tumpu ini kuat, pengetahuan dan keterampilan bekerja secara seimbang dengan kepribadian yang berpengaruh pada perubahan perilaku positif dalam konseling.

Salah satu karakteristik kualitas kepribadian konselor yang berkaitan dengan keefektifan konseling adalah pengetahuan mengenai diri sendiri (self-knowledge). Pengetahuan akan diri sendiri mempunyai makna bahwa seorang guru BK mengetahui secara baik tentang dirinya, apa yang dilakukan, mengapa melakukan itu, masalah apa yang sedang dihadapi dan masalah yang dihadapi oleh klien.

Dalam kehidupan sehari-hari, kata kepribadian digunakan untuk menggambarkan identitas diri/jati diri seseorang, kesan tentang diri anda atau orang lain, serta fungsi-fungsi kepribadian yang sehat atau bermasalah. Identitas pribadi didasarkan pada keunikan karakteristik pribadi seseorang, seperti karakter, kemapuan, bakat dan pilihan. Setiap orang ingin membangun identitas dirinya, memperlihatkan siapa dirinya yang sebenarnya dan kesamaan mereka dengan sejumlah orang dan apa yang membedakan mereka dengan orang lain.

Salah satu penciri identitas adalah fashion dan gaya hidup. Fashion menjadi bagian yang tidak dapat dilepaskan dari penampilan dan gaya keseharian. Benda-benda seperti baju dan aksesori yang dikenakan bukanlah sekadar penutup tubuh dan hiasan, lebih dari itu juga menjadi sebuah alat komunikasi untuk menyampaikan identitas pribadi. Dalam perkembangan selanjutnya fashion tidak hanya menyangkut soal busana dan aksesoris semacam perhiasan seperti kalung dan gelang, akan tetapi benda-benda fungsional lain yang dipadukan dengan unsur-unsur desain yang canggih dan unik menjadi alat yang dapat menunjukkan dan mendongkrak penampilan si pemakai (Hendariningrum \& Edy Susilo, 2008)

Setiap individu mempunyai identitas ganda (multiple subject identities), yang secara sadar atau tidak dikontruksi dan dipelihara, termasuk didalamnya umur, ras, gender, kebangsaan, etnisitas, orientasi seksualitas, kepercayaan agama, dan kelas (Hadi, 2009). Identitas diri adalah perasaan-perasaan yang berasal dari apa yang individu pikirkan mengenai dirinya dan apa yang individu pikir orang lain pikirkan 
mengenai diri individu tersebut (Gardner, 1992). Individu yang sedang membentuk identitas diri adalah individu yang ingin menentukan siapakah dan apakah dirinya pada saat ini serta siapakah atau apakah yang individu inginkan di masa yang akan datang (Ristianti, 2008).

Sebagai makhluk budaya, manusia mencoba membangun identitas mereka dalam relasi sosial dan kultural mereka, untuk menegaskan posisi individual dan sosial suatu komunitas di hadapan orang atau komunitas lain (Suminar, 2011: 19). Seseorang yang mempunyai identitas diri yang kuat maka akan memandang dirinya berbeda dengan orang lain, unik dan tidak ada duanya. Individu yang memiliki identitas diri yang kuat akan memandang dirinya sebagai suatu kesatuan yang utuh dan terpisahkan dari orang lain dan individu tersebut akan mempertahankan identitasnya walau dalam kondisi sesulit apapun (Keliat, 1992). Konstruksi identitas kemudian menjadi proses melibatkan "identitas diri yang ditunjukkan" yang diklaim individu sebagai identitas dan "penempatan identitas" dibuat oleh orang lain yang mendukung identitas untuk diklaim. Identitas sosial tidak datang dan terbentuk dengan sendirinya. Dalam pembentukan identitas terdapat proses-proses motivasi. Tanpa motivasi, individu tidak akan tahu dirinya sendiri, apa yang harus dilakukan dan bagaimana meraka harus melakukannya.

Penelitian yang dilakukan Suminar (2013), membahas mengenai konstruksi identitas guru profesional secara umum dalam perannya sebagai komunikator pendidikan, memunculkan pengkategorian makna identitas guru dan makna guru profesional dimana diperlukan karakter tertentu yang harus dimiliki. Penulis ingin memperdalam bahasan ini dengan mengambil topik yang lebih spesifik, yakni mengenai guru BK. Dalam penelitian lain, Susi Fitri (2011) mencoba menganalisis narasi diri mahasiswa calon konselor sekolah, bertujuan untuk mengetahui berbagai pengalaman diskriminasi yang mereka hadapi dan yang mereka miliki dalam lingkungan multikultur serta bagaimana mereka mengkonstruksi pengalaman tersebut. Nurtyasrini dan Hafiar memaparkan:

Pengalaman seseorang bisa sama. Namun makna dari pengalaman itu berbedabeda bagi setiap orang. Maknalah yang membedakan pengalaman orang satu dengan pengalaman orang lainnya. Makna juga yang membedakan pengalaman yang satu dan pengalaman lainnya. Suatu pengalaman bisa menjadi bagian dari kesadaran, juga karena orang memaknainya. Hanya melalui tindak memaknailah kesadaran orang bisa menyentuh dunia sebagai suatu struktur teratur (organized structure) dari segala sesuatu yang ada di sekitar kita (2016: 221).

Sama halnya dalam penelitian ini penulis juga ingin menggali pengalaman nyata para informan dalam perannya sebagai guru BK dan komunikator pendidikan yang kemudian membentuk konstruksi identitasnya. Atas dasar uraian inilah peneliti merancang penelitian fenomenologis yang bertujuan untuk mengungkap Konstruksi Identitas Guru Bimbingan dan Konseling Sekolah Menengah Atas di Kota Bandung. Penelitian ini memiliki beberapa tujuan, yaitu: (1) untuk mengetahui dan mengungkapkan motivasi yang melatarbelakangi menjadi seorang guru bimbingan dan konseling, (2) untuk mengetahui dan mengungkap makna profesi guru bimbingan dan konseling, dan (3) untuk mengetahui pengalaman komunikasi guru bimbingan dan konseling sebagai komunikator pendidikan.

\section{METODE PENELITIAN}

Penelitian ini menggunakan metode penelitian kualitatif dengan pendekatan fenomenologi, yang paling tepat untuk menjelaskan fenomena sosial dari sudut pandang guru BK sebagai subjek penelitian. Metode penelitian kualitatif dipilih karena peneliti akan menggali dan memahami konstruksi identitas guru bimbingan dan konseling berdasarkan perspektif subjek penelitian. Selain itu, penelitian kualitatif akan membantu untuk memperoleh pemahaman yang otentik mengenai pengalaman seseorang, sebagaimana dirasakan orang yang bersangkutan. Pendekatan yang digunakan adalah fenomenologi, yang berupaya untuk menjelaskan makna pengalaman hidup sejumlah orang tentang suatu konsep atau gejala, termasuk di dalamnya konsep diri atau pandangan hidup mereka sendiri.

Teknik pengumpulan data yang dilakukan oleh peneliti untuk mendapatkan informasi yang dibutuhkan adalah wawancara mendalam. Wawancara ini akan dilakukan kepada guru BK yang terpilih untuk menjadi informan. 
Aspek yang akan ditanyakan kepada informan berkaitan dengan riwayat menjadi pengajar di SMA, motivasi menjadi guru, pendekatan yang dilakukan ketika berkomunikasi dengan siswa-siswi yang sedang berkonsultasi atau sedang bermasalah, persepsi personal guru BK dan hal-hal apa saja yang memengaruhi dalam pembentukan identitas diri guru BK.

Subjek penelitian mengenai konstruksi identitas guru BK ini yakni guru BK yang memiliki ciri-ciri atau karakteristik tertentu. Subjek penelitian ini dipilih secara purposive berdasarkan aktifitas mereka sebagai guru BK dan kesedian mereka menceritakan pengalaman mereka dalam menghadapi siswa-siswi. Mengingat cakupan penelitian dan keterwakilan tiap rayon SMA Negeri di Kota Bandung, maka diputuskan bahwa 7 orang key informant sudah cukup memadai untuk melaksanakan penelitian ini.

Key informant atau narasumber penelitian ini adalah guru BK yang tercatat sebagai guru BK Sekolah Menengah Atas Negeri di Kota Bandung. Diambil minimal satu orang dari perwakilan setiap rayon di Kota Bandung. Adapun kriteria informan, yaitu: (a) tercatat sebagai guru BK tetap di Sekolah Menengah Atas Negeri di Kota Bandung, (b) masa jabatan guru BK di atas 10 tahun, (c) sudah mendapatkan sertifikasi, dan (d) mengikuti salah satu organisasi bimbingan dan konseling.

\section{HASIL DAN PEMBAHASAN}

Teori konstruksi sosial tidak dapat dilepaskan dari bangunan teoretik yang telah dikemukakan oleh Peter L. Berger dan Thomas Luckmann. Peter L. Berger merupakan sosiolog dari New School for Social Research, New York, sementara Thomas Luckman adalah sosiolog dari University of Frankfurt (Nurhadi, 2015: 121). Individu membangun sendiri pengetahuan atas realitas yang dilihat berdasarkan pada struktur pengetahuan yang telah ada sebelumnya yang disebut dengan konstruksi sosial. Konstruksi sosial atas realitas didefinisikan sebagai proses sosial melalui tindakan dan interaksi dimana individu menciptakan secara terus-menerus suatu realitas yang dimiliki dan dialami bersama secara subjektif. Realitas merupakan hasil ciptaan manusia kreatif melalui kekuatan konstruksi sosial terhadap dunia di sekelilingnya. Max
Weber melihat realitas sosial sebagai perilaku sosial yang memiliki makna subjektif. Oleh karena itu, perilaku memiliki tujuan dan motivasi (dalam Bungin, 2008: 188).

Teori identitas memusatkan perhatiannya pada hubungan saling memengaruhi di antara individu dengan struktur sosial yang lebih besar. Pengertian identitas berdasarkan pada pemahaman tindakan manusia dalam konteks sosialnya. Hal tersebut dianggap penting dilakukan untuk mengetahui posisi siapa kita dan siapa mereka, siapa diri (self) dan siapa yang lain (others). Teori identitas memberikan pemahamannya pada ide yang luas tentang diri dan sosialnya. Identitas diri adalah gabungan dari aspek eksternal individu yang membentuk identitas diri.

Identitas merupakan satu unsur kunci dari kenyataan subjektif dan sebagai kenyataan subjektif, berhubungan secara dialektif dengan masyarakat (Berger dan Luckmann (2013: 235). Identitas seseorang dibentuk oleh prosesproses sosial, begitu memperoleh wujudnya, ia dipelihara, dimodifikasi atau malahan dibentuk ulang oleh hubungan-hubungan sosial. Identitas juga dapat didefinisikan sebagai sebuah budaya, sosial, hubungan dan kesan seseorang mengenai konsep diri. Identitas memiliki anggota kelompok, interpersonal dan merupakan implikasi refleksi diri individu. Identitas adalah kaleidoskop yang berwarna dengan karakteristik yang dinamis. (Littlejohn dan Foss, 2009: 492)

Teori Identitas Sosial pertama kali dikembangkan pada awal tahun 1979 oleh Tajfel dan Turner. Tajfel dan Turner mengkonsepkan identitas individu terdiri dari dimensi identitas sosial dan identitas personal dalam tingkatan psikologi. Identitas sosial terdiri dari keanggotaan identitas kultur atau etnik, identitas gender, identitas orientasi seksual, identitas kelas sisial atau identitas peran sosial. Sedangkan identitas personal terdiri dari semua atribut unik yang kita asosiasikan denga diri kita sendiri dibandingkan dengan orang lain. Kedua dimensi identitas personal tersebut memengaruhi perilaku kita dalam kehidupan sehari-hari.

Identitas berasal dari bahasa Inggris, 'identity', yang memiliki pengertian secara harfiah; ciri, tanda atau jati diri yang melekat pada seseorang, kelompok atau sesuatu sehingga membedakan dengan orang lain. Menurut Berger dan Luckmann (2013: 235), identitas 
merupakan suatu unsur kunci dari kenyataan subjektif. Identitas selalu berhubungan secara dialektik dengan masyarakat. Identitas dibentuk oleh proses-proses sosial. Begitu memperoleh wujudnya, ia dipelihara, dimodifikasi atau malah dibentuk ulang oleh hubungan-hubungan sosial.

Menurut Weiner (dalam Nursalam dan Efendi, 2008: 14), motivasi didefinisikan sebagai kondisi internal yang membangkitkan kita untuk bertindak, mendorong kita mencapai tujuan tertentu dan membuat kita tetap tertarik dalam kegiatan tertentu. Motivasi seseorang dapat timbul dan tumbuh berkembang melalui dirinya sendiri - intrinsik dan dari lingkungan - ekstrinsik. Keinginan yang muncul dari diri sendiri untuk bertindak tanpa adanya rangsangan dari luar dapat disebut dengan motivasi intrinsik. Sedangkan motivasi yang datang dari luar individu dapat disebut dengan motivasi ekstrinsik. Motivasi menjadi guru terbagi menjadi dua tipe motivasi, yaitu motivasi intrinsik dan motivasi ekstrinsik.

Hasil penelitian pada key informant mengungkapkan bahwa terdapat empat guru yang memiliki motivasi intrinsik, yaitu subjek A, C, E dan F. Subjek A menjadi guru karena merupakan cita-citanya sejak kecil. Berawal dari kesenangannya bermain "sekolahsekolahan" bersama anak-anak tetangga dan anak-anak saudara yang ternyata secara tidak sadar memunculkan rasa senang pada dunia pendidikan dan ingin memiliki prestasi di dunia pendidikan. Selepasnya sekolah menengah, ia memilih untuk meneruskan kuliah pada jurusan Bimbingan Penyuluhan di IKIP Bandung. Pemilihan jurusan itu didasarkan pada kesenangan subjek A dalam membimbing dan berbagi ilmu dengan anak-anak.

Motivasi ekstrinsik adalah segala sesuatu yang diperoleh melalui pengamatan sendiri, ataupun melalui saran, anjuran atau dorongan dari orang lain. Hasil dari penelitian ini menunjukkan bahwa motivasi ekstrinsik muncul dari dorongan keluarga dan lingkungan.

Pada subjek D dan $G$, motivasi muncul dalam dirinya dipengaruhi oleh faktor eksternal yang berasal dari luar diri individu. Dorongan orang tua yang membuat subjek D memutuskan untuk memilih untuk mendaftarkan dirinya ke IKIP Bandung dan memutuskan untuk menjadi seorang guru. Setelah menjalani sebagai guru BK, ia baru menyadari bahwa keberadaan guru BK itu penting. Dukungan dan dorongan dari anggota keluarga semakin menguatkan untuk menekuni pilihannya. Sama seperti subjek D, subjek G juga memutuskan untuk menjadi seorang guru karena dorongan dari orang tua yang berpendapat bahwa pekerjaan yang paling cocok untuk wanita/perempuan adalah menjadi seorang guru. Hasil penelitian menunjukkan bahwa subjek B menjadi guru BK karena lingkungan pergaulan/pertemanan yang mendorong beliau untuk memilih program studi Psikologi Bimbingan dan Konseling.

Pembahasan selanjutnya mengenai pemaknaan bimbingan konseling yang telah disampaikan oleh tujuh orang informan, menyatakan bahwa guru BK adalah: (a) guru sekaligus orang tua, (b) guru yang menyenangkan, (c) guru yang membantu siswa mengenali dirinya, (d) guru yang harus mengetahui segala hal, (e) guru yang masih dianggap sebagai polisi sekolah, (f) guru yang sempurna, dan (g) guru yang hanya dianggap sebagai "ganjal pintu".

Makna adalah "produk sosial" atau "ciptaan yang dibentuk dalam dan melalui pendefinisian aktivitas manusia ketika mereka berinteraksi. Hasil penelitian menunjukkan bahwa para guru memaknai profesi guru BK secara positif dan negatif. Makna positif dinyatakan dengan guru sekaligus orang tua, guru yang menyenangkan, guru yang membantu siswa mengenali dirinya, guru yang harus mengetahui segala hal, dan guru yang sempurna. Makna positif ini menunjukkan bahwa seorang guru BK merupakan guru yang harus dapat menunjukkan perilaku yang baik, sabar dan santun karena guru BK merupakan seorang guru yang menjadi contoh bagi siswa bimbingannya, sama halnya dengan orang tua menjadi contoh bagi anak-anaknya.

Makna negatif dinyatakan dengan guru yang masih dianggap sebagai polisi sekolah dan guru yang hanya dianggap sebagai "ganjal pintu". Makna negatif ini dijelaskan oleh dua orang key informant bahwa masih ada yang menganggap guru BK itu sebagai polisi sekolah. Anggapan bahwa guru BK adalah polisi sekolah ini masih tertanam di benak beberapa siswa ajaran baru yang belum mengetahui manfaat akan keberadaan guru BK. Selain itu, masih ada pihak sekolah yang meminta guru BK untuk melakukan razia siswa. Padahal tugas tersebut bukanlah wewenang guru BK, karena hal tersebut dapat membingungkan posisi guru 
BK itu sendiri. Guru hanya dianggap sebagai "ganjal pintu", anggapan ini muncul pada saat jam kelas BK dihilangkan dan mereka selalu diminta untuk mengisi jam kelas pada mata pelajaran lain jika guru mata pelajaran tersebut tidak dapat hadir.

Menurut Berger dan Luckmann (2013), manusia adalah makhluk yang memproyeksikan makna ke dalamalam semesta. Manusiamemberi makna dan menumbuhkan nilai kepada bendabenda dan menciptakan tata susunan pengertian yang luas (bahasa, sistem lambang, lembaga) yang merupakan pedoman yang mutlak diperlukan dalam hidupnya. Masih menurut Berger dan Luckmann (2013) dalam teori Konstruksi Sosial bahwa individu membangun sendiri pengetahuan atas realitas yang dilihat berdasarkan pada struktur pengetahuan yang telah ada sebelumnya. Pemaknaan yang muncul dalam diri merupakan hasil dari pengalaman mereka selama menjalani pekerjaannya sebagai guru BK. Ketujuh key informant adalah guru BK yang telah cukup memiliki pengalaman dalam membimbing maupun mengajar, mayoritas telah memiliki masa kerja lebih dari 25 tahun.

Temuan lain dari penelitian ini mengenai makna guru BK profesional yang diungkapkan oleh key informant adalah: (1) memiliki empat kompetensi, yaitu pedagogik, kepribadian, sosial dan profesional, (2) memiliki latar belakang pendidikan BK, (3) mengetahui kode etik, dan (4) guru yang diatur oleh kompetensi profesi.

Dengan begitu guru BK profesional adalah guru yang memiliki latar pendidikan atau pelatihan BK dan dalam melaksanakan tugasnya mampu menampilkan kinerja atas penguasaan kompetensi akademik kependidikan dan kompetensi penguasaan substansi dan atau bidang studi, mengetahui dan menjalankan kode etik.

Tanpa komunikasi kegiatan konseling tidak akan berjalan dengan baik. Guru BK sebagai komunikator berinteraksi dengan berbagai komponen pendidikan, diantaranya siswa, orang tua dan guru lain. Guru dan siswa merupakan bagian dari system pendidikan yang membutuhkan interaksi yang tinggi. Oleh karena itu, guru dan siswa perlu menjalin komunikasi positif. Dalam menjalin komunikasi tersebut, guru dirasa perlu memiliki soft skill yang dapat menghindarkannya dari kemungkinan terjadinya miscommunication atau misunderstanding sebagai titik pangkal persoalan pembelajaran.

Sebagai komunikator pendidikan, guru BK haruslah mampu berkomunikasi dengan segala pihak terkait dunia pendidikan seperti siswa, sesama guru, kepala sekolah, wali murid, maupun masyarakat umum. Guru BK memiliki

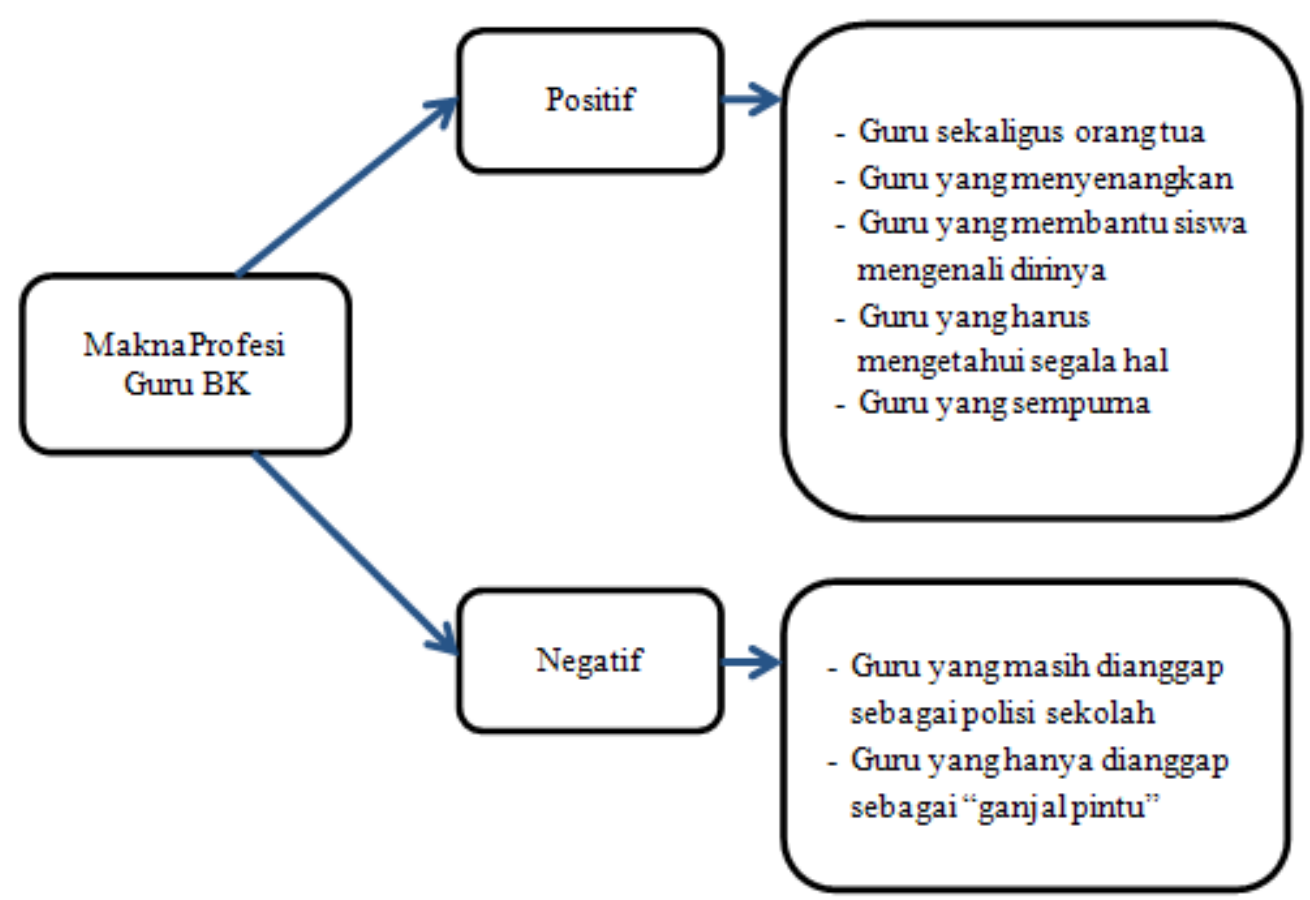

Sumber: Penelitian, 2016

Gambar 1 Makna Profesi Guru Bimbingan dan Konseling 
tanggung jawab lebih untuk membimbing siswa dan membantunya menyelesaikan masalah maupun membimbing mereka dalam keadaan yang lebih personal. Seringkali pendekatan personal tiap anak berbeda, dan sang guru BK harus mampu menyesuaikan kapan dan bagaimana ia harus bersikap dan berbicara kepada perorangan atau kelompok. Guru BK juga dituntut untuk dapat meluruskan persepsi yang salah selama ini terhadap peran guru BK. Tantangan ini seringkali datang dari sesama guru dan dari elemen sekolah itu sendiri. Mulai dari tidak diberikan jam kelas, sampai diminta untuk melakukan razia. Padahal ketentuan dari dinas pendidikan sudah jelas mengenai peran dan tugas guru BK. Inilah yang menuntut para guru BK untuk terus belajar, terutama mengasah kemampuan komunikasinya. Salah satunya dengan cara berbagi pengalaman antar sesamanya. Dari 7 informan yang diwawancara, 5 dari 7 aktif dalam organisasi BK. Seringkali dari sharing itulah didapat ilmu maupun teknik baru dalam menghadapi siswa. Bentuk komunikasinya sendiri tidak bisa hanya verbal saja, tetapi guru BK juga harus memanfaatkan komunikasi non verbal untuk dapat melaksanakan peran BK nya secara optimal. Dari cara berpakaian, cara berbicara, bahasa yang digunakan, sampai penampilan haruslah dijaga agar tidak membuat takut anak-anak yang ingin "curhat". Seringkali guru BK mempelajari "bahasa gaul" maupun julukan khusus yang digunakan siswanya agar lebih mudah berkomunikasi dan menjalin ikatan dengan mereka. Karena disitulah kunci kedekatan guru BK dengan para siswanya.

Ditinjau dari konteks komunikasi yang terjadi antara siswa, orang tua dan guru adalah komunikasi antarpribadi, komunikasi kelompok dan komunikasi organisasional. Pada konteks komunikasi antarpribadi melibatkan hubungan pribadi antara dua individu atau lebih. Dalam proses konseling, komunikasi antar pribadi memungkinkan terjadinya interaksi yang bersifat pribadi antara guru BK dan siswa. Berdasarkan hasil penelitian, komunikasi antarpribadi diterapkan pada bimbingan klasikal yang menuntut guru BK untuk melakukan kontak langsung dengan siswa. Dalam proses konseling, komunikasi antarpribadi memungkinkan terjadinya interaksi yang bersifat pribadi antara guru BK dan siswa. Oleh karena itu, keterampilan komunikasi antarpribadi perlu dikuasai oleh guru BK untuk menunjang keefektifan proses konseling.

Harus diakui bahwa untuk menjalin komunikasi yang sinergis bukanlah hal mudah. Perbedaan latar belakang guru dan siswa, baik itu menyangkut usia dan gender, dapat membuat interaksi yang terjadi rentan terhadap konflik. Dalam hal ini, guru dituntut untuk memiliki rasa empati yang tinggi. Hal ini terungkap pada hasil wawancara subjek E dan F. Yang mengungkapkan bahwa rasa empati perlu dimiliki oleh seorang guru BK. Dengan rasa empati, kesenjangan komunikasi dan toleransi dapat teratasi.

Suyatno dan Jihad (2013: 67) mengungkapkan bahwa seorang pendidik dikatakan berempati bila ia dapat memiliki dan memahami pikiran, perasaan, reaksi, perkembangan, dan motivasi siswanya. Proses berpikir yang dilakukan melibatkan dirinya secara utuh, dengan segala macam resiko perbedaan pendapat, rasa, bahkan kemungkinan konflik.

Hal serupa diungkapkan pula oleh Surya (2009: 114), bahwa untuk terlaksananya suatu komunikasi konseling yang dialogis adalah dengan mengajak klien berpartisipasi aktif. Selain itu, seorang guru BK harus menguasai keterampilan dalam berkomunikasi, yaitu penghampiran, empati, merangkum, bertanya, kejujuran, asertif, konfrontasi dan pemecahan masalah. Salah satu dari delapan keterampilan tersebut, yaitu empati, merupakan keterampilan dasar dalam bekomunikasi yang perlu dimiliki oeleh seorang guru BK. Masih menurut Surya (2009), empati artinya menempatkan diri dalam suasana perasaan, pikiran dan keinginan orang lain sedekat mungkin. Secara psikologis, empati dapat menunjang berkembangnya suasana hubungan yang didasari atas saling pengertian, suasana rasa diterima dan dipahami dan kesamaan diri.

Konteks komunikasi selanjutnya adalah komunikasi kelompok. Kelompok didefinisikan sebagai sekumpulan orang yang mempunyai tujuan bersama yang berinteraksi satu sama lain untuk mencapai tujuan bersama, mengenal satu sama lainnya dan memandang mereka sebagai bagian dari kelompok tersebut (Mulyana, 2005). Komunikasi kelompok ini berlangsung pada saat guru BK memberikan pelayanan bimbingan kepada siswa bimbingannya melalui kelompok-kelompok kecil. Bimbingan ini 
ditujukan untuk merespons kebutuhan dan minat para siswa. Konteks komunikasi terakhir adalah komunikasi organisasi. Komunikasi organisasi yang terjadi pada pelitian ini adalah komunikasi sesama guru BK yang tergabung di MGBK (Musyawarah Guru Bimbingan dan Konseling). Guru BK yang tergabung dalam MGBK bekerjasama untuk mencapai tujuan bersama.

Penguasaan akan media komunikasi pun diperlukan oleh guru BK. Media komunikasi adalah suatu alat atau sarana yang digunakan untuk menyampaikan pesan dari komunikator kepada khalayak, seperti media cetak, radio, televisi dan internet. Perkembangan media komunikasi yang sangat cepat menuntut para guru BK untuk menguasainya agar proses bimbingan dan konseling dapat berjalan dengan baik. Pada saat ini guru BK tidak hanya mengurus siswa yang bermasalah saja, namun membantu juga dalam pendataan siswa yang berhak mendapatkan beasiswa, siswa berprestasi hingga membantu siswa dalam pengisian formulir pendaftaran ke perguruan tinggi.

Sosial media pun berperan dalam membantu kinerja guru BK dalam berkomunikasi dengan siswa. Mayoritas guru BK yang menjadi key informant, menggunakan sosial media untuk berkomunikasi dengan siswa tanpa harus bertatap muka. Hal ini guna memudahkan dalam menjangkau siswa lewat media yang akrab dengan mereka. Sosial media yang sering digunakan yaitu Blackberry Messenger (BBM), Whatsapp (WA) dan LINE. Penggunaaan sosial media ini ternyata berpengaruh pada kedekatan antara guru BK dengan siswa dan menciptakan persepsi positif terhadap guru BK.

George Herbert Mead mengatakan bahwa manusia "berbicara kepada" kemanusiaan. Maksudnya bahwa kita memperoleh identitas pribadi ketika kita berkomunikasi dengan orang lain (Wood, 2013: 4). Identitas dibentuk ketika seseorang secara sosial berinteraksi dengan orang lain.

\section{SIMPULAN}

Berdasarkan paparan yang telah disampaikan, maka dapat ditarik beberapa kesimpulan. Motivasi menjadi guru terbagi menjadi dua tipe motivasi yaitu motivasi intrinsik (merupakan cita-cita sejak kecil) dan motivasi ekstrinsik (dorongan keluarga dan lingkungan). Guru BK sebagai sebuah profesi dimaknai menjadi dua kategori, yaitu makna identitas guru BK sebagai profesi sempurna (positif) dan cadangan (negatif). Makna guru BK positif dinyatakan dengan istilah: guru sekaligus orang tua, guru yang menyenangkan, guru yang membantu siswa mengenali dirinya dan guru yang mengetahui segala hal. Sedangkan makna guru BK sebagai cadangan dinyatakan dengan guru BK hanya dianggap sebagai "ganjal pintu" dan guru yang masih dianggap sebagai polisi sekolah. Pengalaman komunikasi guru BK berlangsung pada tiga konteks komunikasi. Konteks komunikasi yang terjadi adalah konteks komunikasi antarpribadi, kelompok dan organisasional. Konstruksi identitas guru BK sebagai komunikator pendidikan dibangun berdasarkan motivasi yang ada pada diri guru BK, makna akan profesi guru BK dan pengalaman komunikasi guru BK. Guru BK sebagai komunikator pendidikan harus memiliki memiliki kompetensi pedagogik, kepribadian, sosial dan profesional.

Dari hasil penelitian masih ada pihak sekolah yang belum memahami secara mendalam mengenai pentingnya keberadaan guru BK. Oleh karena itu, semua pihak khususnya sekolah perlu mengetahui secara lebih mendalam mengenai keberadaan dan posisi guru BK di sekolah. Idealnya guru bimbingan konseling diberi jam masuk kelas dan ruangan sesuai ketentuan dari dinas pendidikan, agar guru BK dapat menjelaskan kepada siswa tentang program-program yang ada dalam BK dan dapat memberikan layananlayanan secara profesional secara optimal. Dengan begitu, guru BK tidak akan merasa hanya dianggap sebagai "ganjal pintu" oleh pihak sekolah. Fasilitas yang menunjang kegiatan konseling semestinya disediakan oleh sekolah, atau minimal memenuhi syarat minimal yang ditentukan oleh dinas pendidikan. Perlu diwajibkan para guru BK untuk mengikuti organisasi dan aktif didalamnya sebagai wadah silaturahmi dan tukar pikiran antar sesama guru BK. Serta dilakukan evaluasi rutin untuk terus meningkatkan kompetensi dan kinerja guru BK. Mengingat perannya yang besar terhadap keseimbangan psikologi anak, guru BK perlu menguasai ilmu komunikasi dan psikologi. 


\section{DAFTAR PUSTAKA}

Berger, P. L. \& Luckmann, T. (2013). Tafsir sosial atas kenyataan - risalah tentang sosiologi pengetahuan. Jakarta: LP3ES.

Bungin, M. B. (2008). Konstruksi sosial media massa. Jakarta: Kencana.

Fitri, S. (2011). Konstruksi identitas calon konselor sekolah dalam masyarakat multikultur. Jurnal Jabatan Bahasa \& Kebudayaan Melayu. Jilid 3 (2011). Hlm. 119-134.

Gardner, J. E. (1992). Memahami gejolak masa remaja. Jakarta: Mitra Utama.

Hadi, I. P. (2009). Penelitian khalayak dalam perspektif reception analysis. Scriptura, 3(1), 1-7. Retrieved from http://puslit2. petra.ac.id/ejournal/index.php/iko/article/ view/17015.

Hendariningrum, R. \& Susilo, M. E. (2008). Fashion dan gaya hidup: identitas dan komunikasi. Ilmu Komunikasi, 6(2), 25-32.

Keliat, B. A. (1992). Gangguan konsep diri. Jakarta: EGC.

Littlejohn, S. W. \& Foss, K. A. (2009). Encyclopedia of communication theory. Thousand Oaks California: Sage Publication.

Nurhadi, Z. F. (2015). Teori-teori komunikasi: teori komunikasi dalam perspektif penelitian kualitatif. Bogor: Ghalia Indonesia.

Nursalam \& Efendi, F. (2008). Pendidikan dalam keperawatan. Jakarta: Salemba Medika.
Nurtyasrini, S. \& Hafiar, H. (2016). Pengalaman komunikasi pemulung tentang pemeliharaan kesehatan. Jurnal Kajian Komunikasi. Vol. 4, No. 2 Desember 2016. Diakses dari http://journal.unpad.ac.id/jkk/ article/view/10437/5329.

Mulyana, D. (2005). Ilmu komunikasi suatu pengantar. Bandung: Remaja Rosdakarya.

Ristianti, A. (2008). Hubungan antara dukungan sosial teman sebaya dengan identitas diri pada remaja di sma pusaka 1 jakarta. Universitas Guna Darma, 0, 1-28.

Sukmadinata, N. S. (2007). Bimbingan dan konseling dalam praktek, mengembangkan potensi dan kepribadian siswa. Bandung: Maestro.

Suminar, J. R. (2011). Konstruksi identitas guru profesional sebagai komunikator pendidikan. Disertasi, Program Pascasarjana Universitas Padjadjaran.

Suminar, J. R. (2013). Komunikasi antarpribadi. Bandung: Unpad Press.

Suyatno \& Jihad, A. (2013). Menjadi guru profesional - strategi meningkatkan kualifikasi dan kualitas guru di era global. Jakarta: Esensi.

Surya, M. (2009). Psikologi konseling. Bandung: Pustaka Bani Quraisy.

Tajfel, H., \& Turner, J. C. (1979). An integrative theory of social conflict, in austin, w., \& Worschel, s. (Ed.). The Social Psychology Of Intergroup Relations. Monterey: Books Cole.

Wood, J. T. (2013). Komunikasi teori dan praktik. Jakarta: Salemba Humanika. 